\title{
Patient Migration for Hospital Utilization: Case of Iran
}

\author{
Asma Sabermahani', Hosein Ghaderi ${ }^{2}$, Hamid Reza Ashrafzadeh ${ }^{3}$, Farid Abolhasani4, \\ Mohsen Barouni ${ }^{5}$, Gabriele Messina ${ }^{6}$, Nicola Nante ${ }^{6}$ \\ ${ }^{1}$ Research Center for Modeling in Health, Institute for Futures Studies in Health, Kerman University of Medical \\ Sciences, Kerman, Iran \\ ${ }^{2}$ Health Economics Department, School of Health Management and Information Sciences, Iran University of \\ Medical Sciences, Tehran, Iran \\ ${ }^{3}$ Institute of Trade Studies and Research, Tehran, Iran \\ ${ }^{4}$ National Health Institute, Tehran University of Medical Sciences, Tehran, Iran \\ ${ }^{5}$ Research Center for Health Services Management, Institute for Futures Studies in Health, Kerman University \\ of Medical Sciences, Kerman, Iran \\ ${ }^{6}$ Public Health Department of Molecular and Developmental Medicine Area of Public Health, Siena, Italy \\ Email: sabermahany@gmail.com
}

Received 28 January 2014; revised 2 March 2014; accepted 10 March 2014

Copyright (C) 2014 by authors and Scientific Research Publishing Inc.

This work is licensed under the Creative Commons Attribution International License (CC BY).

http://creativecommons.org/licenses/by/4.0/

(c) (i) Open Access

\section{Abstract}

Introduction: Adequate information about patient using health care facilities is a critical element in planning activities and allocation resources in health sector. In Iran, with performing family physician plan and attempt to reform referral system, the study of mobility of patients between regions (patient migration) has more importance. The aims of the study are: 1) to describe patients' migration across cities of Iranian Kerman province; 2) to analyze the role of possible determinants affecting the mobility flows. Methodology: using hospital inpatient records of all public hospitals around Kerman province during 2011, we run logit models that compare patients who were admitted in hospital and received health services in cities where they lived and patients received them out of their local hospitals. We studied 21 patient groups according to ICD10 chapters (Appendix 1) to compute the effect of geographic distance, kind of insurance, number of physiccians involved, hospital bed and patient demographic factors. Results: About 40 percent of hospital admissions in Kerman are emigrant patients that quality or quantity of local provided services didn't satisfy. Constant negative coefficients of geographic distance, hospitals physician and bed and positive coefficients for insurance in all groups do not show any difference in patient migration, between groups. Discussion: According to results of this research, existence of local services, distance, kind of illness and other factors are not more important than patients' feeling about ser-

\footnotetext{
"Corresponding author.
} 
vices in their migration. Paying no attention to this reality in planning health system reforms, especially referral systems, leads to important problems for health system in equity, patient satisfaction and finance aspects.

\title{
Keywords
}

\author{
Patient Migration; Hospital Utilization; Kerman Province
}

\section{Introduction}

Patient migration occurs because of patients' choices or physicians' advices and it have an important role in financing of health care agencies, especially private institutions [1]. Patients' choices are dependent on their culture, economic characteristics, previous healthcare experiences, reputation of the hospital staff and the network of relationships between the patient, hospital doctors and general practitioners/reference specialists [2]. Today, after extensive planning in order to gain equity in access to health care and justly distribution of facilities, continued movement of patients between regions to receive health care services, caused to importance increase of check out this issue and made it considerable.

Adequate accessibility to health care services in all regions means providing the right services at the right time and place, and as individual's ability effects on utilization of health services, all health service delivery policies should be fair to all members of society [3]. There is a direct relation between providing of health care and utilization of them, so there is a relationship between resource allocation and accessibility to health care facilities too [4].

Accessibility to health care services is a requisite for establishing justice in a society and the right to utilize of health care in the community will lead to equal opportunities for all [5]. There are two approaches for measuring accessibility, one of them is measuring potential physical accessibility by calculation of population and facilities ratio and another is studying real accessibility to services by analyzing health care utilization data [6]. The main difference of these two approaches is that the first one is concentrated on facilities characteristics that patients can use them and the second, on patients' characteristics of who used the facilities before. Health care utilization can reflect accessibility, too [7]. Health planners and policy makers know that inaccessibility produce, obviously dissatisfaction of needs or patients' migration.

Several researches, in fact demonstrate, that patient's geographical distance from facilities is one of the most important factors that effect on health hospital in particular, care of utilization [8] [9].

Patients utilization of health care is related to health care supply, level and kind of patients need and their access to services in need time too [5] [10]. Moreover, patients' usage of a health care facility is related to patients' attitude about that facility and their choice [11]. It can be concluded from researches that patients are forced to migrate and accept geographical distance if their health needs don't meet in their local health system. It means unfair distribution of health services in quantity or quality aspects result in patient migration [12].

In developed countries, most of health care utilization and patient migration determinants are specified and analyzed, but it's not true in developing countries [13]. Adequate information about patient using of health care facilities is a critical element for planning and resource allocation in health sector [14].

Many patients despite providing services in their local health areas, use other regions services and this cause decrease in bed occupancy rate in that regions and disruption in health system plans [15].

In Iran, with pilot performing family practitioners plan in some provinces that tries to introduce some general physicians and specific specialists as health system gatekeepers and reform referral system, patients' migration and mobility of patients between regions will have more importance. Whether in this plan, patients have choice about care givers or not, this issue will be noteworthy for analyzing. In the first programs of this plan, patients that not follow referral system will not be benefit from insurance protections and this subject motivate us to gather information for planners about current patient motilities out of referral system and make some alarms about paying no attention to this point.

There is no arrangement to avoid free patient referrals in Kerman province so many patients show bypass behavior and go to nonlocal health facilities and give services that are existence in their local health systems too. Family physician plan want to reform referral system so patient migration analysis can help planners with in- 
formation about patient movements and factors affecting this movements so we try to describe patients' migration across cities of Iranian Kerman province and analyze the role of possible determinants affecting the mobilety flows.

As in many researches it has showed that there is a relation between health care quality and patient migration so with increase of patients awareness in health care facility choice, more refer to one facility can be seen as better quality of that facility [4] [5] [16]. In this case we can analyze provided cares quality indirectly with analyzing patient migration model too [15]. Also we can analyze likely differences in migration between northern and southern cities which are recognized different in health, education and income condition in previous studies [17].

\section{Methodology}

We used logit model as a discrete choice model for patient migration study in the biggest province of Iran, "Kerman" inhabitants. We chose this province because in Iran there is no database about hospital patients all together, then we were forced to use Hospital Information Systems (HIS) separately. As this process is very complicated, we chose the biggest province in which there is a large variance in geographical, cultural, economic and social aspects [12]. Kerman province, located in South-East Iran, is divided to 16 cities with capital of Kerman city.

As there is no information about patient movements around the country, in this research, we use hospital inpatient records in all public hospitals around Kerman province during 2011. We gathered all hospital inpatients records separately through hospital information systems that are not linked to each other.

Each patient admitted in hospital has an electronic record, in which all patient information is registered. Final diagnose code that is entered as one of International Classification Codes (ICD) is the only useful data for dividing patient in the base of their disease in the Kerman hospitals' record.

We gathered all inpatient records and excluded patients from other provinces. Then using about 50,000 data ran logit models that compare patients who received hospital services in the cities that they live in, and who receive them out of it, in each diagnostic group and a total logit model for all data.

Logit model can be used in conditions that dependent variable is binary. By this model, first we can calculate the probability of patient migration for receive hospital services and second marginal effect of any explanatory variable. Marginal effect is change in probability of dependent variable occurrence in exchange for one unit increase in explanatory variables. Dependent variable in this research, is migration to use hospital services that take zero if patient received hospital services in the city that live in, and one when received services out of it.

Because there are unlimited factors that have influence on patient migration, choosing suitable explanatory variables for the research is the first part of running the logit model. According to last researches, the most important factors that have effect on patient migration are patient demographic factors (gender, age and sex), kind of disease, existence and kind of insurance, geographic distance between patient home and hospital that patient receive care in it and overall attractiveness of facilities for patients that are identified as number of physicians and beds [2] [14] [18] [19].

The importance of geographic distance and factors about provided services in the model is strongly related to kind of disease so in some studies patient migration is checked in specific disease groups or patients were considered in research divided groups, we studied patients in 21 groups according to ICD10 chapters and run 21 logit models to emphasize on different characteristics of disease. The biggest specified model was:

Equation (1): biggest logit model for disease groups.

$$
Y=\alpha_{0} \operatorname{dis}_{i j}+\alpha_{1}\left(\operatorname{bed}_{i} / \operatorname{bed}_{j}\right)+\alpha_{3}\left(\mathrm{dr}_{i} / \mathrm{dr}_{j}\right)+\alpha_{4} \operatorname{sex}+\alpha_{5} \text { age }+\alpha_{6} \mathrm{dtam}+\alpha_{7} \mathrm{dkh}+e \cdot i j t
$$

In this model $Y$ take 1 if patient in the hospital is from another city and 0 if patient receive services in city that he/she live in it. dis $i_{i j}$ is the distance between I, city that patient receive hospital services (destination) that in our study is Kerman city, and $j$ city that patient live in it (origin). Bed is the number of inpatient bed per 1000 population in $i$ and $j$ cities. dr is ratio of physician (general and specialist) to population in cities. dtam and dkh are dummy variables for kinds of insurance programs that we compare them to without insurance coverage patients.

There are several public hospitals in some cities so we were forced to merge all hospitals data in each city. We considered some variables in ratio form for easier interpretation and less parameter estimation.

Primary model in each group was analyzed and after specification and estimation, effective variables were 
determined. Coefficients in logit model are not suitable for reasonable interpretation so we calculated marginal effects in the next step. In each model we analyze goodness of fit by Hosmer-Lemeshow test and heteroskedasticity with Davidson and MacKinnon test.

\section{Results}

Gathered hospital data showed that in 2011, there is no patient flows between cities except between Kerman city and other cities. This means that patients migrate just to capital and not to other cities. About 40 percent of inpatients in each Kerman hospital were from other cities (19,756 patients in all hospitals). Table 1 shows patient migration percent in each disease group. Most migration happened in groups 15 (Pregnancy and childbirth), 9 (Diseases of the circulatory system) and 18 (signs and abnormal clinical and laboratory findings). Recorded patients in group 5 and 20 were few and therefore excluded from the study. More assessment of inpatients codes suggested that almost all of the patients received services have been provided in the local health areas too.

Figure 1 shows patient migration from each city. According to results, about 21 percent of migrations are related to Bam patients. Jiroft and Bardsir are two next ones in this case. In this table we didn't consider city population.

Table 2 shows that, the most migration in each group is related to which city and in this case city population is considered. Most migrations in this table are from Bardsir, Jiroft and Kahnuj.

After descriptive analysis of research data, results of specified and estimated models for each group is reported in Table 3. Coefficient sign for physician, distance in kilometer unit and insurances in all groups is invariant and it means that these factors have similar effects on patient migration in all groups. In most groups, patient migration decrease with increasing in geographic distance and this influence is larger in Group 7. Increas-

\section{Table 1. Patient migration percent in ICD10 groups.}

\begin{tabular}{ccc}
\hline Patient Group & Migration percent \\
\hline I & 2.56 \\
II & 7.15 \\
III & 2.21 \\
IV & 2.1 \\
V & 0.13 \\
VI & 2.47 \\
VII & 5.54 \\
VIII & 0.57 \\
IX & 12.31 \\
X & 6.19 \\
XI & 5.52 \\
XII & 0.69 \\
XIII & 1.52 \\
XIV & 10.19 \\
XV & 12.52 \\
XVI & 2.16 \\
XVII & 2.33 \\
XVIII & 11.21 \\
XIX & 4.62 \\
XX & 0 \\
XXI & 8 \\
\hline & 0 \\
\hline
\end{tabular}


Table 2. Cities with the most migration in each ICD10 group.

\begin{tabular}{cccccc}
\hline ICD group & most migration & ICD group & most migration & ICD group & most migration \\
\hline I & 1-Jiroft 2-Kahnuj & VIII & 1-Jiroft 2-Kahnuj & XV & 1-Bardsir 2-Ravar \\
II & 1-Jiroft 2-Bardsir & IX & 1-Bardsir 2-Kahnuj & XVI & 1-Bardsir 2-Manujan \\
III & 1-Jiroft 2-Kahnuj & X & 1-Bardsir 2-Kahnuj & XVII & 1-Jiroft 2-Zarand \\
IV & 1-jiroft 2-ravar & XI & 1-Bardsir 2-Jiroft & XVIII & 1-Bardsir 2-Kahnuj \\
V & 1-Kuhbanan2- Jiroftj & XII & 1-Kahnuj 2-Baft & XIX & 1-Bardsir 2-Zarand \\
VI & 1-Bardsir 2-Kahnuj & XIII & 1-jiroft 2-Zarand & XX & 1-Bardsir 2-Bam \\
VII & 1-Qalehkanj 2-Kahnuj & XIV & 1-jiroft 2-Kahnuj & XXI & \\
\hline
\end{tabular}

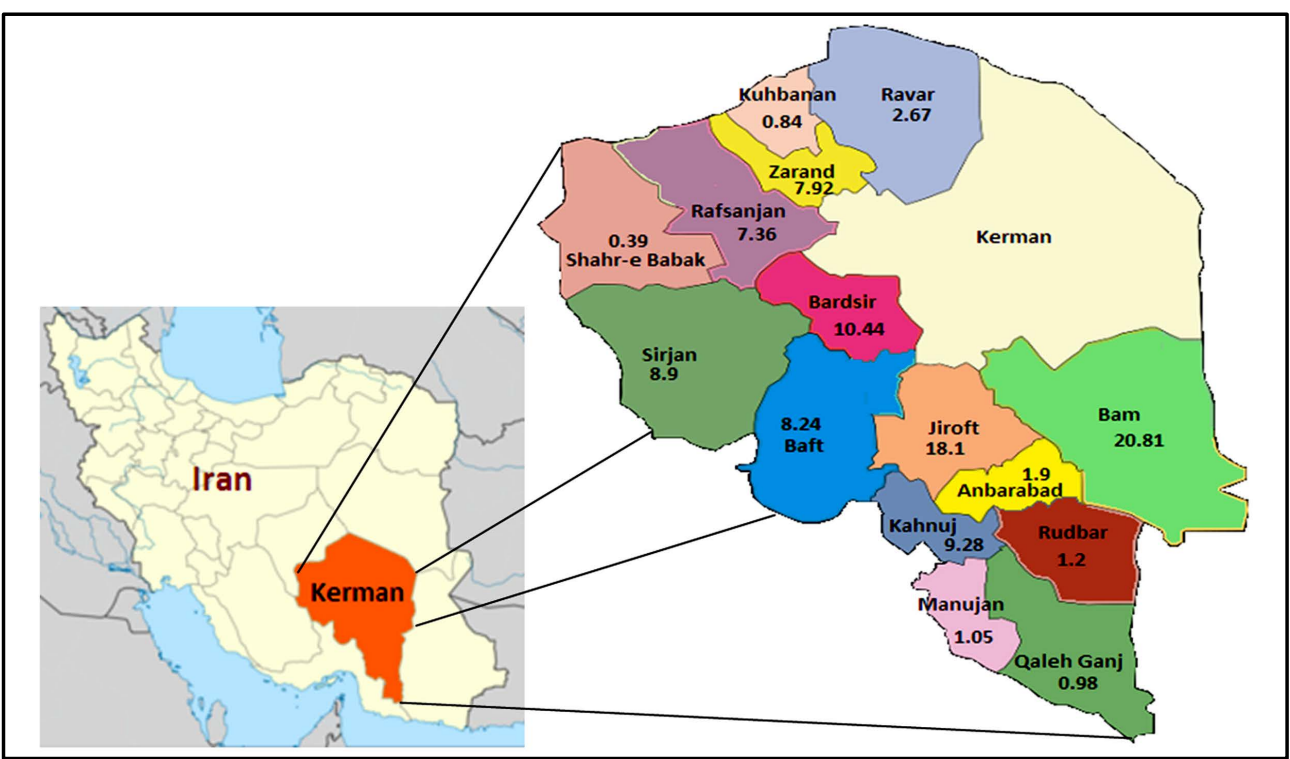

Figure 1. Patient migration percent from cities to Kerman.

ing in physician ratio in origin and destination, lead to patient migration decrease and this decrease is more obvious in group 7 too. Insurance dummy variables had positive relation with patient migration in all groups and it means that patients with insurance in any kind, migrated more than patient without health insurance.

Age and sex factors had different effects in different disease groups. Results of total logit model for all data are reported in Equation (2).

Equation (2): total logit model for all data:

$$
\text { Mig }_{\text {total }}=\underset{(-18.11)}{-0.002 \mathrm{dis}}-\underset{(-19.22)}{1.38 \mathrm{dr}}-\underset{(-46.07)}{0.91 \mathrm{bed}}+\underset{(1.84)}{0.0001 \mathrm{age}}+\underset{(2.38)}{0.007 \mathrm{sex}}+\underset{(15.57)}{0.1 \mathrm{dtam}}+\underset{(7.99)}{0.05 \mathrm{dkh}}
$$

According to Equation (2), totally migration increase with age increasing. Women migrate more than men and with increasing in distance, physician and bed ratio, migration will decrease.

\section{Discussion}

One of our results is confirmation of geographic distance effect on patient migration in a developing country however this effect is very small in this research. Most of researches about health services accessibility and utilization of them like Levaggi, Nante and Baker showed that distance has negative effect on use of health care services [1] [7] [15]. In Fabry research, the effect of distance is reported in four groups and distance had more effect on migration in basic medicine, basic surgeries, complex surgeries and cancer respectively [20]. In our study, the estimated coefficients of distance are negative but very small because the most migrations were from 
the farthest cities. Despite most migration to Kerman carried out from furthest cities, geographical distance factor has significant effect in all groups except groups 8 and 12 and we can conclude that migrations is effected by distance in Kerman like other places and many patients in far cities from big services centers are not able to migrate.

Cities of Kerman province are very different and this issue is demonstrated in several studies like researcher study in 2000 and 2006 [17]. According to this study northern cities have better condition in health, education and income than southern cities and have higher human development index and Jiroft is the worst city in health index. In our study it is proven that most migrations are from cities that had lower human development index than other cities in Kerman province. In Table 3, Jiroft, Kahnuj, Manujan and Qalehganj are among poor devel-

Table 3. Independent variables marginal effect in 21 models with $\mathrm{Z}$ statistics.

\begin{tabular}{|c|c|c|c|c|c|c|c|c|}
\hline Dependent variable & Intercept & Geographical distance & Physician & Hospital bed & Sex & Age & Insurance 1 & Insurance 2 \\
\hline Migicd $_{\text {icd }}$ & $\begin{array}{c}-2.4 \\
(-3.78)\end{array}$ & $\begin{array}{l}-0.003 \\
(-6.62)\end{array}$ & $\begin{array}{c}-1.62 \\
(-6.37)\end{array}$ & & & & $\begin{array}{l}+0.08 \\
(3.31)\end{array}$ & $\begin{array}{l}+0.08 \\
(3.06)\end{array}$ \\
\hline $\operatorname{Mig}_{\text {icd } 2}$ & $\begin{array}{c}2.47 \\
(4.02)\end{array}$ & $\begin{array}{l}-0.0035 \\
(-4 / 36)\end{array}$ & $\begin{array}{c}-2.03 \\
(-3.76)\end{array}$ & & & $\begin{array}{l}-0.005 \\
(-5.29)\end{array}$ & $\begin{array}{c}0.12 \\
(1.80)\end{array}$ & $\begin{array}{l}0.24 \\
(3.4)\end{array}$ \\
\hline Mig $_{\text {icd } 3}$ & $\begin{array}{c}4.13 \\
(2.96)\end{array}$ & $\begin{array}{l}-0.008 \\
(-3.16)\end{array}$ & $\begin{array}{c}-3.74 \\
(-2.79)\end{array}$ & & & $\begin{array}{l}-0.008 \\
(-3.82)\end{array}$ & & $\begin{array}{l}+0.33 \\
(4.40)\end{array}$ \\
\hline $\operatorname{Mig}_{\text {icd } 4}$ & $\begin{array}{c}2.23 \\
(2.91)\end{array}$ & $\begin{array}{c}-0.0056 \\
(-3.87)\end{array}$ & $\begin{array}{l}-2.61 \\
(-3.46)\end{array}$ & & & & $\begin{array}{l}+0.47 \\
(2.68)\end{array}$ & $\begin{array}{l}+0.57 \\
(3.15)\end{array}$ \\
\hline Mig $_{\text {icd } 6}$ & $\begin{array}{c}2.87 \\
(4.95)\end{array}$ & $\begin{array}{l}-0.006 \\
(-5.34)\end{array}$ & $\begin{array}{l}-2.88 \\
(-5.39)\end{array}$ & & & & $\begin{array}{c}+0.097 \\
(2.8)\end{array}$ & $\begin{array}{l}+0.011 \\
(2.99)\end{array}$ \\
\hline Mig $_{\text {icd } 7}$ & $\begin{array}{c}9.17 \\
(5.16)\end{array}$ & $\begin{array}{l}-0.017 \\
(-5.18)\end{array}$ & $\begin{array}{c}-8.4 \\
(-5.17)\end{array}$ & & $\begin{array}{c}-0.05 \\
(-2.03)\end{array}$ & $\begin{array}{l}-0.003 \\
(-5.16)\end{array}$ & & $\begin{array}{l}+0.07 \\
(2.48)\end{array}$ \\
\hline Mig $_{\text {icd } 8}$ & & & & & & $\begin{array}{c}-0.01 \\
(-6.02)\end{array}$ & & \\
\hline Mig $_{\text {icd } 9}$ & $\begin{array}{c}-2.8 \\
(7.09)\end{array}$ & $\begin{array}{l}-0.003 \\
(-6.19)\end{array}$ & $\begin{array}{c}-2.01 \\
(-6.33)\end{array}$ & $\begin{array}{c}-1.01 \\
(-12.48)\end{array}$ & & $\begin{array}{l}-0.001 \\
(-3.69)\end{array}$ & $\begin{array}{l}+0.05 \\
(2.37)\end{array}$ & $\begin{array}{l}+0.12 \\
(5.36)\end{array}$ \\
\hline Migi $_{\text {icd } 10}$ & $\begin{array}{c}1.21 \\
(75.5)\end{array}$ & $\begin{array}{l}-0.001 \\
(-4.64)\end{array}$ & $\begin{array}{c}-0.93 \\
(-5.37)\end{array}$ & $\begin{array}{c}-0.61 \\
(-10.37)\end{array}$ & & & $\begin{array}{l}+0.09 \\
(4.09)\end{array}$ & $\begin{array}{l}+0.06 \\
(2.72)\end{array}$ \\
\hline Migi $_{\text {icd } 11}$ & $\begin{array}{c}44.1 \\
(43.5)\end{array}$ & $\begin{array}{c}-0.001 \\
(-4.4)\end{array}$ & $\begin{array}{l}-1.03 \\
(-4.76)\end{array}$ & $\begin{array}{c}-0.75 \\
(-11.2)\end{array}$ & $\begin{array}{l}+0.04 \\
(2.97)\end{array}$ & $\begin{array}{c}+0.0008 \\
(2.83)\end{array}$ & $\begin{array}{c}+0.032 \\
(1.61)\end{array}$ & $\begin{array}{l}+0.05 \\
(2.35)\end{array}$ \\
\hline Migigd $12_{12}$ & $\begin{array}{c}-0.12 \\
(-8.76)\end{array}$ & & & & & & & $\begin{array}{l}+0.05 \\
(2.42)\end{array}$ \\
\hline Migi $_{\text {icd } 13}$ & $\begin{array}{c}1.01 \\
(46.3)\end{array}$ & $\begin{array}{c}-0.01 \\
(-3.72)\end{array}$ & & $\begin{array}{c}-1.96 \\
(-4.15)\end{array}$ & $\begin{array}{l}+0.19 \\
(3.03)\end{array}$ & $\begin{array}{l}-0.004 \\
(-2.58)\end{array}$ & & $\begin{array}{l}+0.25 \\
(3.58)\end{array}$ \\
\hline Migigd 14 & $\begin{array}{l}-3.84 \\
(14.5)\end{array}$ & $\begin{array}{c}-0.004 \\
(-4.8)\end{array}$ & $\begin{array}{l}-2.91 \\
(-4.85)\end{array}$ & $\begin{array}{l}-1.34 \\
(-9.7)\end{array}$ & & $\begin{array}{c}+0.002 \\
(4.18)\end{array}$ & $\begin{array}{l}+0.13 \\
(3.74)\end{array}$ & $\begin{array}{l}+0.19 \\
(5.19)\end{array}$ \\
\hline Migicd 15 & $\begin{array}{c}1.62 \\
(77.8)\end{array}$ & $\begin{array}{l}-0.001 \\
(-6.53)\end{array}$ & $\begin{array}{c}-0.99 \\
(-6.86)\end{array}$ & $\begin{array}{c}-0.83 \\
(-20.25)\end{array}$ & $\begin{array}{c}-0.17 \\
(-4.26)\end{array}$ & $\begin{array}{c}+0.002 \\
(2.23)\end{array}$ & $\begin{array}{l}+0.03 \\
(1.97)\end{array}$ & $\begin{array}{l}+0.04 \\
(2.67)\end{array}$ \\
\hline Migicd 16 & $\begin{array}{c}0.94 \\
(56.5)\end{array}$ & $\begin{array}{l}-0.002 \\
(-8.19)\end{array}$ & $\begin{array}{c}-0.89 \\
(-16.18)\end{array}$ & & & & $\begin{array}{c}+0.06 \\
2.6\end{array}$ & $\begin{array}{c}+0.08 \\
3.15\end{array}$ \\
\hline Migicd 17 & $\begin{array}{c}3.24 \\
(85.1)\end{array}$ & $\begin{array}{l}-0.005 \\
(-2.16)\end{array}$ & $\begin{array}{c}-3.02 \\
(-1.91)\end{array}$ & & & $\begin{array}{l}-0.006 \\
(-3.46)\end{array}$ & $\begin{array}{l}+0.57 \\
(3.08)\end{array}$ & $\begin{array}{l}+0.46 \\
(2.39)\end{array}$ \\
\hline Migicd $18_{18}$ & $\begin{array}{c}2.84 \\
(11.32)\end{array}$ & $\begin{array}{c}-0.006 \\
(-12.42)\end{array}$ & $\begin{array}{c}-2.91 \\
(-12.2)\end{array}$ & & $\begin{array}{c}-0.06 \\
(-3.46)\end{array}$ & & $\begin{array}{l}+0.08 \\
(2.95)\end{array}$ & $\begin{array}{l}+0.17 \\
(6.42)\end{array}$ \\
\hline Migicd 19 & $\begin{array}{c}0.58 \\
(59.6)\end{array}$ & $\begin{array}{l}-0.001 \\
(-5.24)\end{array}$ & $\begin{array}{l}-0.38 \\
-5.22\end{array}$ & $\begin{array}{l}-0.32 \\
-15.21\end{array}$ & $\begin{array}{l}+0.01 \\
(3.30)\end{array}$ & & & $\begin{array}{l}+0.02 \\
(4.78)\end{array}$ \\
\hline Migi $_{\text {icd } 21}$ & $\begin{array}{c}2.22 \\
(91.3)\end{array}$ & $\begin{array}{l}-0.002 \\
(-9.08)\end{array}$ & $\begin{array}{l}-1.23 \\
-2.57\end{array}$ & $\begin{array}{c}-1.54 \\
3.92\end{array}$ & $\begin{array}{l}+0.07 \\
(2.62)\end{array}$ & $\begin{array}{l}-0.004 \\
(-5.77)\end{array}$ & $\begin{array}{l}+0.14 \\
(3.03)\end{array}$ & $\begin{array}{l}+0.29 \\
(6.07)\end{array}$ \\
\hline
\end{tabular}


oped cities. However geographic distance has negative effect on migration and mentioned cities have most distances from Kerman, nevertheless most migrations were from these cities. This point clarifies poor accessibility to health care or at least qualified services from the perspective of patients in these cities.

In some researches like Roh and Lee study [15], hospital factors such as physician and bed are mentioned as effective factors on patient mobility. In our research number of physicians and hospital beds had negative effect on patient migration, this means increasing in physician and hospital bed numbers in any city lead to decrease in migration from that city. This result is discussable with two views, one from Roh and Lee approach that number of physician and beds in hospitals has a mental effect on patients and these are psychological attractive factors and another view that increasing in hospital physician and bed means increase in accessibility to hospital services.

According to literature, having health insurance have positive effect on health care utilization, in our study this factor is known effective in all disease groups too.

With increase in patient age, migration increase and this is acceptable because of more need of elderly people to hospital services. Patient migration suggest, there are deficiencies in the local health services, in another hand the elderly population is increasing so with no change in health care providing system we should expect increase in patient migration in future years.

Finally, the issue of patients' mobility between regions in the situation of the country's implementation of the proposed scheme of family physician is an undeniable necessity. On the one hand, people freedom to choose health care providers along with financing system reforms (financing related to provided patient cares) lead to resource flows toward the centers that are more accepted by patients. This situation increase competition power of more accepted centers and lead other centers to going out of competition. In this case planners should pay attention to physician interests in some hospitals. In another hand, ignoring patient right for choosing between providers, Means a failure to comply justice in health utilization system. In present health system if patient be confronted with inadequate or unqualified hospital services, can migrate to another hospital, so there is debate about hospital capacity for providing satisfactory services for all local people, in almost all cities hospitals. Considering patient migration as hospitals lack of accountability, common in last researches, implementation of family physician program will followed by serious problems for cities hospital care providers and patients.

In primary family physician scheme, out of referral system health care utilization results in patients being denied of the benefits and protections of health insurances and this means more complicated situation for equity and more financial problems for patients who has less accessibility to qualified services. Often health care inaccessibility is associated with patients and regions deprivation so elimination health insurance protection for migrant patients means more catastrophic payments that are unsolved until now.

\section{Acknowledgements}

This study was part of a Ph.D. thesis supported by Iran University of Medical Sciences (grant No: IUMS/ SHMIS_1391/632).

\section{References}

[1] Nante, N., Ricciardi, G., Al Farraj, O., Morgagni, S., Siliquini, R., Moirano, F., et al. (2003) Hospital Patient Migration: Analysis Using an Utility Index. Public Health in Europe, 293-316.

[2] Messina, G., Forni, S., Collini, F., Quercioli, C. and Nante, N. (2013) Patient Mobility for Cardiac Problems: A Risk-Adjusted Analysis in Italy. BMC Health Services Research, 13, 56.

[3] Goodridge, D., Hawranik, P., Duncan, V. and Turner, H. (2012) Socioeconomic Disparities in Home Health Care Service Access and Utilization: A Scoping Review. International Journal of Nursing Studies, 1, 1310-1319.

[4] Chernew, M., Scanlon, D. and Hayward, R. (1998) Insurance Type and Choice of Hospital for Coronary Artery Bypass Grafi Surgery. Health Services Research, 33, 447-466.

[5] Hodgkin, D. (1996) Specialized Service Offerings and Patient's Choice of Hospital: The Case of Cardiac Catheterization. Health Economics, 15, 305-332. http://dx.doi.org/10.1016/0167-6296(96)00004-5

[6] Gulliford, M. and Morgan, M. (2003) Access to Health Care. New Fetler LAN Routledge, London.

[7] Baker, J.B. (2005) Examining Spatial Patterns of Primary Health Care Utilization in Southern Honduras. University of Cincinnati, Cincinnati.

[8] Buor, D. (2002) Distance as a Predominant Factor in the Utilisation of Health Services in the Kumasi Metropolis, 
Ghana. GeoJournal, 56, 145-157. http://dx.doi.org/10.1023/A:1022452311911

[9] Rickettsa, T. and Randolp, R. (2001) Hospitalization Rates as Indicators of Access to Primary Care. Health and Place, 7, 27-38.

[10] Robert, S. (1983) Distance and the Utilization of Health Facilities in Rural Nigeria. Social Science and Medicine, 17, 563-570. http://dx.doi.org/10.1016/0277-9536(83)90298-8

[11] Penchansky, D. and Thomas, J. (1981) The Concept of Access: Definition and Relationship to Consumer Satisfaction. Medical Care, 19, 127-140. http://dx.doi.org/10.1097/00005650-198102000-00001

[12] Mooney, G., Hall, J., Donaldson, C. and Gerard, K. (1991) Utilisation as a Measure of Equity: Weighing Heat? Journal of Health Economics, 10, 475-480. http://dx.doi.org/10.1016/0167-6296(91)90026-J

[13] Bailey, W. and Phillips, D. (1990) Spatial Patterns of Use of Health Services in the Kingston Metropolitan Area, Jamaica. Social Science and Medicine, 30, 1-12. http://dx.doi.org/10.1016/0277-9536(90)90324-L

[14] Müller, I., Smith, T., Mellor, S., Rare, L. and Genton, B. (1998) The Effect of Distance from Home on Attendance at a Small Rural Health Centre in Papua New Guinea. International Journal of Epidemiology, 27, 878-884. http://dx.doi.org/10.1093/ije/27.5.878

[15] Roh, C.Y. and Lee, K.H. (2006) Hospital Choice by Rural Medicare Beneficiaries: Does Hospital Ownership Matter. Journal of Health and Human Services Administration, 28, 346-365.

[16] Messina, G., Vigiani, N., Lucia, L. and Nante, N. (2008) Patient Migration among the Italian Regions in 2003. Italian Journal of Public Health, 5, 45-52.

[17] Sabermahani, A., Hadian, M., Ghaderi, H., Barouni, M., Shakibaee, A. and Bahrami, M.A. (2012) Comparing the Efficiency of Kerman Province Towns in Acquiring Human Development Index via Data Envelopment Analysis. Iranian Red Crescent Medical Journal, 14, 248-249.

[18] Ishida, Y., Ohde, S., Takahashi, O., Deshpande, G., Shimbo, T. and Hinohara, S. (2012) Factors Affecting Health Care Utilization for Children in Japan. Pediatrics, 129, 113-119. http://dx.doi.org/10.1542/peds.2011-1321

[19] Poorreza, A., Khabiry, T. and Arab, M. (2008) Analysing Health Seeking Behavior in Tehran City Population. Health College Journal, 7, 1-13.

[20] Fabbri, D. and Robone, S. (2010) The Geography of Hospital Admission in a National Health Service with Patient Choice. Health Economics, 19, 1029-1047. http://dx.doi.org/10.1002/hec.1639 


\section{Appendix 1. ICD10 Chapters or Groups}

\begin{tabular}{|c|c|c|}
\hline Chapter I & Certain infectious and parasitic diseases & (A00-B99) \\
\hline Chapter II & Neoplasms & $(\mathrm{C} 00-\mathrm{D} 48)$ \\
\hline Chapter III & $\begin{array}{c}\text { Diseases of the blood and blood-forming organs and certain } \\
\text { disorders involving the immune mechanism }\end{array}$ & (D50-D89) \\
\hline Chapter IV & Endocrine, nutritional and metabolic diseases & (E00-E90) \\
\hline Chapter V & Mental and behavioral disorders & (F00-F99) \\
\hline Chapter VI & Diseases of the nervous system & (G00-G99) \\
\hline Chapter VII & Diseases of the eye and adnexa & (H00-H59) \\
\hline Chapter VIII & Diseases of the ear and mastoid process & (H60-H95) \\
\hline Chapter IX & Diseases of the circulatory system & (I00-I99) \\
\hline Chapter X & Diseases of the respiratory system & (J00-J99) \\
\hline Chapter XI & Diseases of the digestive system & (K00-K93) \\
\hline Chapter XII & Diseases of the skin and subcutaneous tissue & (L00-L99) \\
\hline Chapter XIII & Diseases of the musculoskeletal system and connective tissue & (M00-M99) \\
\hline Chapter XIV & Diseases of the genitourinary system & (N00-N99) \\
\hline Chapter XV & Pregnancy, childbirth and the puerperium & (O00-O99) \\
\hline Chapter XVI & Certain conditions originating in the prenatal period & (P00-P96) \\
\hline Chapter XVIII & Symptoms, signs and abnormal clinical and laboratory findings, not elsewhere classified & (R00-R99) \\
\hline Chapter XX & External causes of morbidity and mortality & (V01-Y98) \\
\hline Chapter XXI & Factors influencing health status and contact with health services & (Z00-Z99) \\
\hline
\end{tabular}

